\title{
PENGGUNAAN MODEL BAMBOO DANCING DALAM PEMBELAJARAN PKn DI SEKOLAH DASAR
}

\author{
Suci Lucyana ${ }^{1)}$, Farida ${ }^{2}$, Reinita $^{3)}$ \\ 1) Mahasiswa, Universitas Negeri Padang, Indonesia \\ 2) Pembimbing 1, Universitas Negeri Padang, Indonesia \\ 3) Pembimbing 2, Universitas Negeri Padang, Indonesia \\ ${ }^{1)}$ lucyanasuci@yahoo.com, ${ }^{2)}$ faridasuarman1960@ gmail.com, \\ 3)reinita_reinita@yahoo.com
}

\begin{abstract}
Abstrak
Tujuan penelitian ini adalah untuk mendeskripsikan peningkatan hasil belajar siswa dalam pembelajaran PKn dengan model kooperatif tipe bamboo dancing di kelas V SDN 16 Kampeh. Jenis penelitian ini adalah penelitian tindakan kelas dengan menggunakan pendekatan kualitatif dan kuantitatif. Subjek penelitian ini adalah guru dan siswa kelas V berjumlah 20 orang. Penelitian dilaksanakan dalam dua siklus. Prosedur penelitian meliputi perencanaan, pelaksanaan, pengamatan, dan refleksi. Hasil penelitian menunjukkan peningkatan pada a) RPP siklus I 82,14\% dan siklus II 92,86\% , b) Pelaksanaan pada aspek guru siklus I 77,5\% dan siklus II 90\%, c) Pelaksanaan pada aspek siswa siklus I 81,25\% dan siklus II menjadi 92,5\%, d) Hasil belajar siswa siklus I 78,47 dan siklus II 86,64. Dengan demikian dapat disimpulkan, dengan menggunakan model pembelajaran bamboo dancing dapat meningkatkan hasil belajar siswa dalam pembelajaran PKn.
\end{abstract}

Kata kunci: hasil belajar; Pendidikan Kewarganegaraan; bamboo dancing

\section{USING OF BAMBOO DANCING MODEL IN LEARNING CIVIC EDUCATION AT ELEMENTARY SCHOOL}

\begin{abstract}
The purpose of this study was to describe the learning outcome of students in learning Civic Education by using bamboo dancing type of cooperative learning model in class $V$ SDN 16 Kampeh. This type of research is a classroom action research using qualitative and quantitative approaches. The subjects were teachers and students of class $V$, totaling 20 people. The research was conducted in two cycles. The procedure includes research, planning, implementation, observation, and reflection. The results showed increased in a) RPP of first cycle $82.14 \%$ and second cycle $92.86 \%$, b) Implementation in the teachers aspect of first cycle $77.5 \%$ and second cycle 90\%, c) Implementation in the student aspect of first cycle $81.25 \%$ and second cycle to $92.5 \%$, d) Student learning outcomes of first cycle 78.47 and second cycle 86.64. It can be concluded, using of bamboo dancing learning model can improve student learning outcomes in Civics learning.
\end{abstract}

Keywords: learning outcomes;Civic Education;bamboo dancing 


\section{PENDAHULUAN}

Pendidikan Kewarganegaraan (PKn) merupakan salah satu mata pelajaran yang sangat penting dipelajari terutama di Sekolah Dasar (SD). Pembelajaran PKn merupakan mata pelajaran yang tidak hanya memuat penanaman konsep/pengetahuan semata, tetapi di dalamnya memuat semua aspek Pendidikan Kewarganegaraan. Aspek Pendidikan Kewarganegaraan itu meliputi penanaman sikap/karakter, dan penanaman keterampilan sebagai bekal dalam membentuk warga negara yang demokratis. Lebih lanjut Depdiknas (2006:271) mengemukakan bahwa "Mata pelajaran PKn di Sekolah Dasar (SD) merupakan mata pelajaran yang memfokuskan pada pembentukan warga negara yang memahami dan mampu melaksanakan hak-hak dan kewajibannya untuk menjadi warga negara Indonesia yang cerdas, terampil, dan berkarakter yang diamanatkan oleh Pancasila dan UUD 1945".

Pembelajaran PKn lebih memfokuskan pada pembentukan karakter yang bertujuan agar siswa memiliki pengetahuan dan kemampuan untuk menjadi warga negara yang baik, serta memiliki kepribadian yang baik sebagai warga negara Indonesia. Dengan pembelajaran PKn diharapkan nantinya siswa dapat menjadi warga negara yang memiliki komitmen kuat dan konsisten untuk mempertahankan NKRI.

Tujuan pembelajaran PKn lebih memfokuskan pada pembentukan karakter siswa sehingga keterlibatan siswa dalam hal ini sangatlah penting. Untuk itu idealnya pembelajaran PKn adalah pembelajaran yang melibatkan siswa secara aktif di dalam proses pembelajaran itu sendiri. Dalam hal ini usaha guru sangatlah dituntut. Guru dituntut untuk dapat memiliki kemampuan dan keterampilan dalam menampilkan materi sebaik mungkin yang juga memerlukan teknik penyampaian tersendiri sehingga pembelajaran menjadi menarik dan menyenangkan bagi siswa, sehingga siswa dapat terlibat secara aktif. Selain itu guru juga harus mampu menggunakan berbagai cara agar pembelajaran lebih bermakna dan dapat dikuasai siswa sehingga dapat berpengaruh terhadap proses pembelajaran dan hasil belajar siswa nantinya. Guru haruslah kreatif dan inovatif dalam setiap pembelajaran. Guru harus memilki cara agar di dalam pembelajaran itu semua siswa dapat menjadi aktif.

Berdasarkan observasi yang peneliti lakukan pada tanggal 31 Agustus 2017, 7 dan 14 September 2017 di kelas V SD Negeri 16 Kampeh Kecamatan Baso Kabupaten Agam penulis menemukan adanya permasalahan yang timbul dalam pembelajaran PKn. Permasalahan tersebut diantaranya: (1) guru kurang memberikan kesempatan kepada siswa untuk saling bertukar pikiran dalam pembelajaran, (2) guru kurang memberikan kesempatan kepada siswa untuk mengeluarkan pendapat, (3) guru kurang memberikan kesempatan kepada siswa untuk bekerjasama saat pembelajaran.

Permasalahan di atas mengakibatkan siswa mengalami hal-hal sebagai berikut : (1) pembelajaran kurang menarik bagi siswa, (2) 
siswa pasif dalam menerima materi pelajaran,

(3) siswa sulit memahami materi pelajaran.

Permasalahan-permasalahan

tersebut

mengakibatkan hasil belajar siswa rendah.

Hal ini terbukti dengan rendahnya nilai MID

PKn semester I siswa tahun pelajaran

2017/2018 dimana nilai rata-rata kelas 67 .

Dari 20 orang yang terdiri dari 14 siswa perempuan dan 6 siswa laki-laki di kelas tersebut, hanya 7 orang siswa (35\%) yang tuntas dan 13 orang siswa (65\%) yang tidak tuntas. Kriteria Ketuntasan Minimal (KKM) untuk mata pelajaran PKn yang ditetapkan sekolah yaitu 75 .

Alternatif yang dapat digunakan untuk pemecahan masalah tersebut adalah dengan penggunaan model pembelajaran yang melibatkan siswa secara langsung dan terlibat aktif berinteraksi antara siswa dalam membangun sendiri pengetahuannya. Salah satu model pembelajaran yang dianggap sesuai adalah model pembelajaran kooperatif tipe bamboo dancing.

Menurut Suprijono (2013: 98), model bamboo dancing merupakan pembelajaran kelompok yang diatur berpasangan dimana model pembelajaran ini menuntut siswa untuk lebih aktif dan berinteraksi antara sesamanya dalam memahami materi pembelajaran Langkah-langkahnya yaitu: (1) pengenalan topik, (2) pembentukan kelompok besar dengan cara membagi kelas menjadi 2 kelompok lalu tiap siswa dalam kelompok berdiri berpasangan, (3) membagikan tugas kepada setiap pasangan, (4) bergeser searah jarum jam untuk bertukar pasangan dalam berbagi informasi, (5) mempresentasikan hasil diskusi tiap-tiap kelompok besar.

Kelebihan model kooperatif tipe bamboo dancing adalah (1) siswa dapat bertukar pengalaman atau berbagi informasi sesamanya dengan pasangan yang berbeda, meningkatkan keterampilan berkomunikasi siswa, (3) meningkatkan kerja sama antara siswa (Istarani, 2012:200).

Dari uraian di atas, rumusan masalah yang ada dalam penelitian ini yaitu (1) Bagaimanakah rencana pelaksanaan pembelajaran untuk meningkatkan hasil belajar siswa pada pembelajaran PKn dengan model kooperatif tipe bamboo dancing di kelas V SD Negeri 16 Kampeh Kecamatan Baso? (2) Bagaimanakah pelaksanaan pembelajaran untuk meningkatkan hasil belajar siswa pada pembelajaran PKn dengan model pembelajaran kooperatif tipe bamboo dancing di kelas V SD Negeri 16 Kampeh Kecamatan Baso? (3) Bagaimanakah peningkatan hasil belajar siswa pada pembelajaran PKn dengan model pembelajaran kooperatif tipe bamboo dancing di kelas V SD Negeri 16 Kampeh Kecamatan Baso?

Berdasarkan rumusan masalah di atas, tujuan dari penelitian ini adalah untuk mendeskripsikan peningkatan hasil belajar siswa pada pembelajaran PKn dengan menerapkan model pembelajaran kooperatif tipe bamboo dancing di kelas V SD Negeri 16 Kampeh Kecamatan Baso. 


\section{METODE PENELITIAN}

Penelitian ini merupakan Penelitian Tindakan Kelas (PTK). Menurut Wardhani, dkk (2007:1.4) "Penelitian tindakan kelas adalah penelitian yang dilakukan oleh guru di dalam kelasnya sendiri melalui refleksi diri, dengan tujuan untuk memperbaiki kinerjanya sebagai guru, sehingga hasil belajar siswa menjadi meningkat".

Jenis pendekatan yang digunakan adalah pendekatan kualitatif dan kuantitatif. Penelitian ini terdiri dari dua siklus yaitu siklus 1 dan siklus 2. Data penelitian ini berupa hasil pengamatan, diskusi, dan dokumentasi dari pembelajaran PKn dengan model pembelajaran bamboo dancing pada siswa kelas V Sekolah Dasar terteliti. Sumber data penelitian diperoleh melalui proses pembelajaran PKn dengan model bamboo dancing di kelas V SD Negeri 16 Kampeh Kecamatan Baso meliputi 20 orang siswa yang terdiri dari 14 orang perempuan dan 6 orang laki-laki, serta guru kelas V sebagai subjek penelitian.

Data yang telah terkumpul dianalisis dengan tahapan: (1) Menelaah data yang telah terkumpul baik melalui observasi dan tes. (2) Menyajikan data dilakukan dengan cara mengorganisasikan informasi yang sudah direduksi. Data tersebut mula-mula disajikan terpisah, tetapi setelah tindakan terakhir direduksi, keseluruhan data tindakan dirangkum dan disajikan secara terpadu. (3) Menyimpulkan hasil penelitian.

Teknik pengumpulan data penelitian ini diperoleh melalui obeservasi dan tes. Teknik observasi digunakan untuk mengumpulkan data perencanaan dan pelaksanaan proses pembelajaran yang meliputi penyusunan RPP, pelaksanaan guru dan siswa. Tes digunakan untuk mengumpulkan data nilai siswa pada aspek kognitif.

Instrument penelitian terdiri dari lembar observasi yang digunakan untuk mengumpulkan data perencanaan (RPP) dan pelaksanaan tindakan baik untuk tindakan guru maupun siswa saat proses pembelajaran berlangsung, butir-butir soal objektif yang diberikan untuk mengukur sejauh mana pemahaman dan penguasaan materi pembelajaran dari unsur siswa. Sedangkan format penilaian skala sikap untuk mengukur aspek sikap dan format penilaian psikomotor untuk mengukur aspek keterampilan siswa.

Model analisis data kuantitatif yaitu terhadap hasil belajar siswa dengan menggunakan pendekatan persentase yang dirumuskan oleh Purwanto (2006:102) dengan rumus sebagai berikut:

$$
\mathrm{NP}=\frac{R}{S M} \times 100 \%
$$

Dimana NP $=$ Nilai persen yang dicari, $\mathrm{R}=$ Jumlah skor yang diperoleh, dan SM = Jumlah skor maksimal

\section{HASIL PENELITIAN}

\section{Siklus I}

Penelitian dilaksanakan dengan tahapan perencanaan, pelaksanaan, pengamatan, dan refleksi. Siklus I terdiri dari dua kali pertemuan yaitu pada hari Kamis tanggal 18 Januari 2018 pukul 10.30-11.40 WIB dan hari Kamis tanggal 25 Januari 2018 pukul 10.30- 
11.40 WIB. Alokasi waktu untuk setiap pertemuan adalah 2 x 35 menit.

\section{Perencanaan}

Perencanaan disusun dan diwujudkan dalam bentuk Rencana Pelaksanaan Pembelajaran (RPP). Pembuatan RPP ini disusun oleh peneliti sendiri sebagai guru kelas berdasarkan program semester II sesuai dengan waktu penelitian berlangsung. Perencanaan pada siklus I tiap pertemuan dilaksanakan dengan alokasi waktu 2x35 menit.

Penilaian terhadap RPP dilaksanakan melalui lembar penilaian RPP dengan aspek penilaian yang terdiri dari: (a) kejelasan perumusan tujuan pembelajaran, (b) pemilihan materi pembelajaran, (c) pengorganisasian materi ajar, (d) pemilihan sumber/media pembelajaran, (e) kejelasan proses pembelajaran, menyusun langkahlangd) teknik pembelajaran, (f) teknik pembelajaran, (g) kelengkapan instrument.

Berdasarkan pengamatan yang dilakukan oleh observer, persentase skor pada penilaian RPP siklus I pertemuan $178,57 \%$ dengan kualifikasi baik (B), pada siklus I pertemuan $185,7 \%$ dengan kualifikasi baik (B), rata-rata keberhasilan guru dalam merancang pembelajaran pada siklus I adalah 82,15\% dengan kualifikasi baik (B).

\section{Pelaksanaan}

Berdasarkan RPP yang disusun pelaksanaan tindakan dibagi menjadi tiga tahap yaitu kegiatan awal, kegiatan inti, dan kegiatan akhir, dengan menggunakan model bamboo dancing. Model bamboo dancing dengan langkah-langkahnya: (1) pengenalan topik, (2) pembentukan kelompok besar dengan cara membagi kelas menjadi 2 kelompok lalu tiap siswa dalam kelompok berdiri berpasangan, (3) membagikan tugas kepada setiap pasangan, (4) bergeser searah jarum jam untuk bertukar pasangan dalam berbagi informasi, (5) mempresentasikan hasil diskusi tiap-tiap kelompok besar.

\section{Aspek Guru}

Pelaksanaan dari aspek guru dalam pembelajaran Pkn dengan model bamboo dancing belum tercapai dengan maksimal sesuai dengan rencana yang disusun. Hal tersebut terlihat pada:

Penyampaian tujuan pembelajaran, guru belum menyampaikan tujuan pembelajaran secara jelas dan rinci. Dalam pengenalan topik guru terlihat tergesa-gesa. Pada kegiatan pembentukan kelompok besar guru kurang mengawasi siswa. Pada kegiatan membagikan tugas kepada setiap pasangan guru tidak ada menjelaskan kembali tugas dengan bahasa yang mudah dimengerti. Pada kegiatan bergeser berbagi informasi guru kurang memberikan pengawasan kepada semua pasangan karena terlihat masih ada juga pasangan-pasangan yang berbagi informasi sambil bercanda.

Berdasarkan hasil pengamatan yang dilakukan oleh observer terhadap aspek guru dalam kegiatan pembelajaran PKn dengan model bamboo dancing persentase skor pelaksanaan dari aspek guru siklus I pertemuan $175 \%$ dengan kualifikasi cukup 
(C), pada siklus I pertemuan 2 persentase 80\% dengan kualifikasi baik (B). Dari kedua pertemuan tersebut rata-rata persentase pelaksanaan dari aspek guru pada siklus I adalah $77,5 \%$ dengan kualifikasi cukup (B).

\section{Aspek Siswa}

Pelaksanaan dari aspek siswa dalam pembelajaran PKn dengan model bamboo dancing belum tercapai dengan maksimal sesuai dengan rencana yang disusun. Hal tersebut terlihat pada:

Pada kegiatan awal saat mendengarkan apersepsi guru masih ada siswa yang belum menjawab pertanyaan dengan baik dan benar. Saat mendengarkan guru menyampaikan tujuan pembelajaran masih ada terlihat siswa yang bermain-main tidak serius mendengarkan guru. Pada ssat penyampaian topik oleh guru masih banyak siswa yang tidak berani untuk bercerita ke depan tentang gambar yang dipajang guru untuk memperkenalkan topik. Saat bergabung dalam kelompok masih ada siswa yang rebut dan terlihat menonjolkan diri sendiri.

Berdasarkan hasil pengamatan yang dilakukan oleh observer terhadap aspek siswa dalam kegiatan pembelajaran PKn dengan model bamboo dancing, persentase skor pelaksanaan dari aspek siswa siklus I pertemuan 1 77,5\% dengan kualifikasi baik (B), pada siklus I pertemuan 2 persentase 85\% dengan kualifikasi baik (B). Dari kedua pertemuan tersebut rata-rata persentase pelaksanaan dari aspek siswa pada siklus I adalah $81,25 \%$ dengan kualifikasi baik (B).

\section{Hasil Belajar}

Hasil belajar diperoleh melalui penilaian pada ranah kognitif, afektif dan psikomotor. Hasil belajar siswa pada siklus I pertemuan 1 penilaian kognitif 74,5, penilaian afektif 80,1 dan penilaian psikomotor 73,33. Dilihat dari kriteria keberhasilan belajar, nilai rata-rata kelas siswa pada siklus I pertemuan 1 adalah 75,99. Pada siklus I pertemuan 2 penilaian kognitif 83 , penilaian afektif 83,63 dan penilaian psikomotor 76,25. Dilihat dari kriteria keberhasilan belajar, nilai rata-rata kelas siswa pada siklus I pertemuan 2 adalah 80,96. Rata-rata kelas pada siklus I dengan menggabungkan rata-rata kelas pada pertemuan 1 dan pertemuan 2 adalah 78,47.

Berdasarkan kolaborasi peneliti dengan guru kelas sebagai observer disimpulkan pembelajaran pada siklus 1 sudah telaksana dengan cukup baik karena sudah mencapai target yang ditetapkan sekolah yaitu 75 . Namun masih terdapat beberapa kekurangan, untuk memperbaiki kekurangan yang terjadi pada siklus I peneliti melanjutkan ke siklus II.

\section{Siklus II}

Penelitian dilaksanakan dengan tahapan perencanaan, pelaksanaan, pengamatan, dan refleksi. Penelitian siklus II dilaksanakan 1 kali pertemuan yaitu pada hari Kamis tanggal 1 Februari 2018 pukul 10.30 - 11.40. Alokasi waktu 2 x 35 menit.

\section{Perencanaan}

Pada tahap ini peneliti membuat persiapan untuk pelaksanaan tindakan pada siklus II. Persiapan tersebut disusun dan 
diwujudkan dalam bentuk Rencana Pelaksanaan Pembelajaran (RPP). Pembuatan RPP ini disusun oleh peneliti sendiri sebagai guru kelas berdasarkan program semester I sesuai dengan waktu penelitian berlangsung. Perencanaan pada siklus I pertemuan 1 ini dilaksanakan dengan alokasi waktu 2x35 menit.

Lembar penilaian RPP yang digunakan pada siklus II sama dengan siklus I. Lembar penilaian dengan aspek penilaian yang terdiri dari: (a) kejelasan perumusan tujuan pembelajaran, (b) pemilihan materi pembelajaran, (c) pengorganisasian materi ajar, (d) pemilihan sumber/media pembelajaran, (e) kejelasan proses pembelajaran, menyusun langkah-langd) teknik pembelajaran, (f) teknik pembelajaran, (g) kelengkapan instrument Berdasarkan pengamatan yang dilakukan oleh observer, persentase skor pada penilaian RPP siklus II yaitu 92,86\% dengan kualifikasi sangat baik (SB).

\section{Pelaksanaan}

Berdasarkan RPP yang disusun pelaksanaan tindakan dibagi menjadi tiga tahap yaitu kegiatan awal, kegiatan inti, dan kegiatan akhir, dengan menggunakan model bamboo dancing. (1) pengenalan topik, (2) pembentukan kelompok besar dengan cara membagi kelas menjadi 2 kelompok lalu tiap siswa dalam kelompok berdiri berpasangan, (3) membagikan tugas kepada setiap pasangan, (4) bergeser searah jarum jam untuk bertukar pasangan dalam berbagi informasi, (5) mempresentasikan hasil diskusi tiap-tiap kelompok besar.

\section{Aspek Guru}

Berdasarkan hasil pengamatan yang dilakukan oleh observer terhadap aspek guru dalam kegiatan pembelajaran PKn dengan model bamboo dancing, persentase skor pelaksanaan dari aspek guru siklus II yaitu 90\% dengan kualifikasi sangat baik (SB).

\section{Aspek Siswa}

Berdasarkan hasil pengamatan yang dilakukan oleh observer terhadap aspek siswa dalam kegiatan pembelajaran PKn dengan model bamboo dancing, persentase skor pelaksanaan dari aspek siswa siklus II yaitu 92,5\% dengan kualifikasi sangat baik (SB).

\section{Hasil Belajar}

Hasil belajar diperoleh melalui penilaian pada ranah kognitif, afektif dan psikomotor. Hasil belajar siswa pada siklus II penilaian kognitif 90,5, penilaian afektif 87,75 dan penilaian psikomotor 81,67 . Dilihat dari kriteria keberhasilan belajar pada siklus II, nilai rata-rata kelas yang diperoleh siswa yaitu 86,64 . 


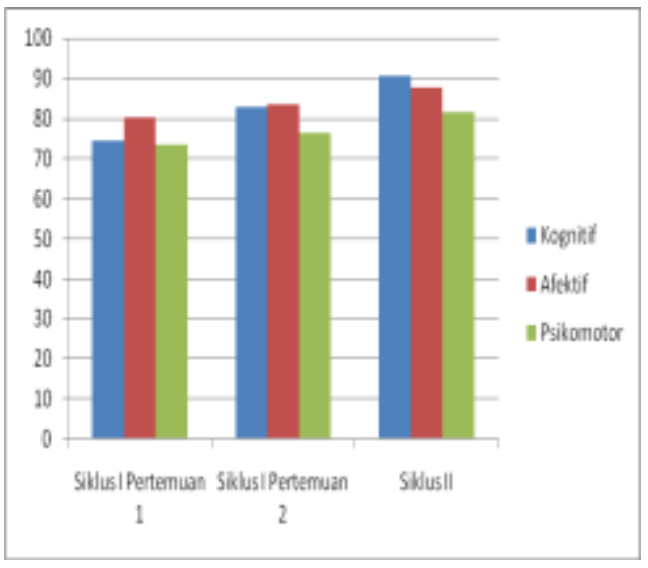

Gambar 1. Peningkatan Hasil Belajar Siswa Dilihat dari Aspek Kognitif, Afektif, dan Psikomotor

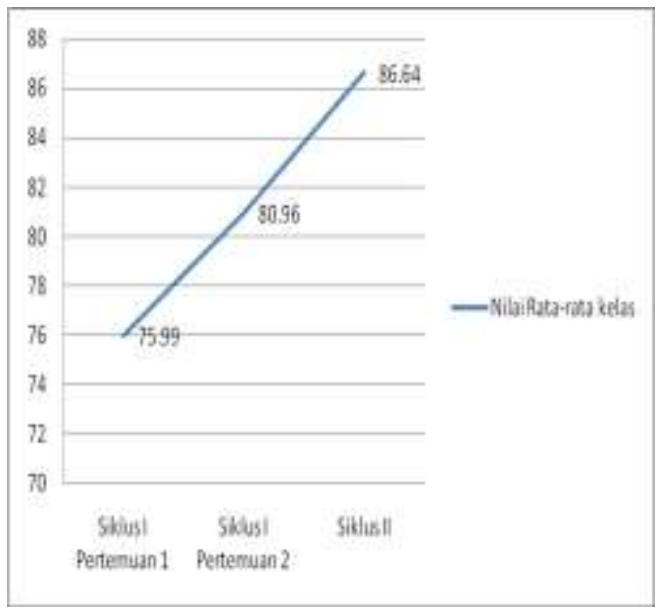

Gambar 2. Peningkatan Nilai Rata-Rata Kelas

Secara umum terlihat adanya peningkatan rata-rata hasil belajar siswa dari awal siklus I sampai ke akhir siklus II.

Hasil penelitian jika ditinjau dari aspek perencanaan (RPP), pelaksanaan (kegiatan guru dan kegitan siswa) juga mengalami peningkatan dari siklus I dan siklus II. Untuk lebih jelasnya dapat dilihat tabel dan grafik di bawah ini:
Tabel 1. Hasil Penilaian RPP, Aspek Guru dan Aspek Siswa

\begin{tabular}{|c|c|c|c|c|c|}
\hline $\begin{array}{c}\mathrm{N} \\
\mathrm{o}\end{array}$ & $\begin{array}{c}\text { Aspek } \\
\text { yang } \\
\text { dinilai }\end{array}$ & $\begin{array}{c}\text { Siklus I } \\
\text { pertemuan } \\
1\end{array}$ & $\begin{array}{c}\text { Siklus I } \\
\text { pertemua } \\
\mathrm{n} \mathrm{2}\end{array}$ & $\begin{array}{c}\text { Rata- } \\
\text { rata }\end{array}$ & $\begin{array}{c}\text { Sikl } \\
\text { us II }\end{array}$ \\
\hline 1 & RPP & $78,57 \%$ & $85,7 \%$ & $\begin{array}{c}82,14 \\
\%\end{array}$ & $\begin{array}{c}92,8 \\
6 \%\end{array}$ \\
\hline 2 & $\begin{array}{c}\text { Aspek } \\
\text { guru }\end{array}$ & $75 \%$ & $80 \%$ & $\begin{array}{c}77,5 \\
\%\end{array}$ & $90 \%$ \\
\hline 3 & $\begin{array}{c}\text { Aspek } \\
\text { siswa }\end{array}$ & $77,5 \%$ & $85 \%$ & $\begin{array}{c}81,25 \\
\%\end{array}$ & $95 \%$ \\
\hline
\end{tabular}

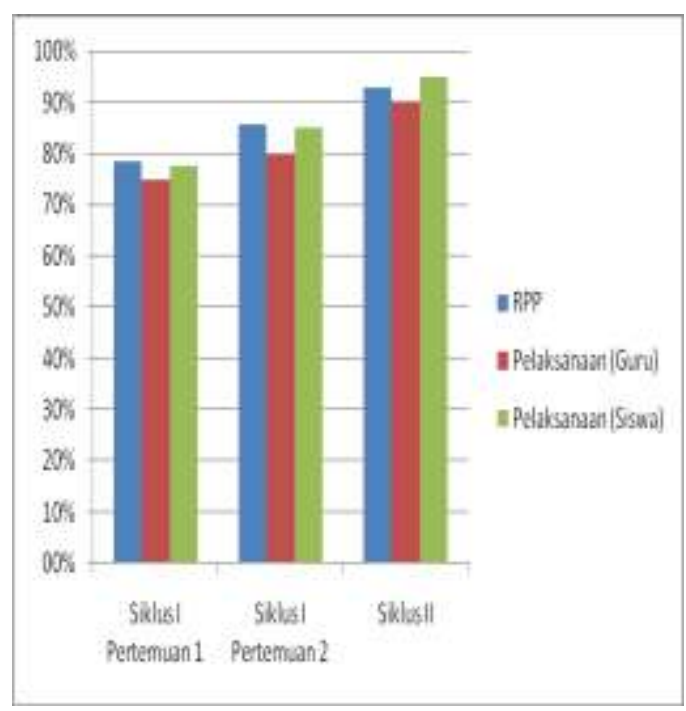

Gambar 3. Hasil Penilaian dari Aspek Perencanaan (RPP), Pelaksanaan Kegiatan Guru dan Siswa

Dari tabel dan grafik di atas dapat diketahui peningkatan dari data hasil penelitian yang dilakukan pada siklus I dan Siklus II yang dilihat dari aspek: 1) RPP siklus I pertemuan 1 dengan persentase $78,57 \%$, siklus I pertemuan 2 pertemuan $85,7 \%$, dan siklus II 92,86\%. 2) Pelaksanaan aspek guru siklus I pertemuan $175 \%$, siklus I pertemuan $280 \%$, dan siklus II 90\%. 3) Pelaksanaan aspek siswa siklus I pertemuan 1 $77,5 \%$, siklus I pertemuan $285 \%$ dan siklus II $95 \%$. 


\section{PEMBAHASAN}

Siklus 1

\section{Perencanaan}

Perencanaan dimulai dengan membuat rancangan pembelajaran dalam bentuk Rencana Pelaksanaan Pembelajaran (RPP) yang harus sesuai dengan komponen RPP. Menurut Permendiknas No. 41 Tahun 2007 tentang Pembelajaran pada Pendidikan Dasar dan Pendidikan Menengah, RPP mencakup: “(1) identitas mata pelajaran, meliputi satuan pendidikan, kelas, semester, mata pelajaran/tema pelajaran, jumlah pertemuan, (2) standar kompetensi; (3) kompetensi dasar, (4) indikator pencapaian kompetensi, (5) tujuan pembelajaran, (6) materi ajar, (7) alokasi waktu, (8) metode pembelajaran, (9) kegiatan pembelajaran, (10) penilaian hasil belajar, (11) sumber belajar".

Dari penyusunan perencanaan siklus I ditemukan beberapa kendala, seperti materi ajar yang tidak sistematis, materi ajar yang tidak sesuai dengan alokasi waktu, kegiatan pembelajaran yang tidak sesuai dengan alokasi waktu. Kendala yang ditemui pada siklus I ini menjadi perhatian dan dicari solusinya, sehingga perencanaan pembelajaran pada siklus II mencapai keberhasilan dengan sangat baik sehingga dapat meningkatkan kemampuan berpikir siswa.

\section{Pelaksanaan}

Pelaksanaan pembelajaran dari aspek guru terdapat beberapa kendala yaitu saat pengenalan topik guru terlihat terburu-buru, saat bergeser bertukar pasangan untuk berbagi informasi guru belum tegas dalam menentukan batasan waktu untuk siswa bertukar pasangan sehingga banyak waktu yang terbuang.

Kemudian pelaksanaan dari aspek siswa juga terdapat beberapa kendala yaitu saat bergeser bertukar pasangan untuk berbagi informasi masih ada siswa yang tidak serius sehingga waktu banyak terbuang dan saat mempresentasikan hasil diskusi siswa belum ada yang berani untuk memberikan tanggapan saat kelompok lain tampil. Menurut Suprijono (2013:99) "langkah-langkah pelaksanaan pembelajaran haruslah sesuai dengan langkah-langkah bamboo dancing yaitu: (1) pengenalan topik, (2) pembentukan kelompok besar, (3) membagikan tugas, (4) bergeser searah jarum jam untuk bertukar pasangan dalam berbagi informasi, mempresentasikan hasil diskusi tiap-tiap kelompok besar".

Berdasarkan analisis data pelaksanaan dari aspek guru diperoleh hasil 77,5\% dan pelaksanaan aspek siswa diperoleh 81,25\%. Pelaksanaan pembelajaran pada siklus I belum sesuai sepenuhnya dengan langkah model bamboo dancing. Oleh sebab itu perlu dicarikan solusi dan diperbaiki pada siklus II.

\section{Hasil Belajar}

Rata-rata hasil belajar siklus I adalah 78,47 dan masih ada 4 orang yang belum tuntas dengan Kriteria Ketuntasan Minimal (KKM) adalah 75. Kunandar (2010:251) menyatakan bahwa "Kriteria ideal ketuntasan belajar masing-masing indikator adalah $75 \%$. Satuan pendidikan diharapkan meningkatkan 
ketuntasan belajar secara terus menerus untuk mencapai ketuntasan ideal. Ketuntasan ideal yaitu ketuntasan yang diharapkan yaitu $\geq 85$ $\%$ siswa mencapai batas KKM yang ditetapkan yaitu 75".

Jika dikaitkan dengan pendapat Kunandar tersebut maka hasil belajar yang diperoleh pada siklus I belum mencapai hasil yang maksimal sehingga perlu dilanjutkan dan diperbaiki pada siklus II.

\section{Siklus II}

\section{Perencanaan}

Perencanaan pembelajaran pada siklus II juga diwujudkan dalam bentuk Rencana Pelaksanaan Pembelajaran (RPP). Dalam membuat RPP haruslah sesui dengan komponen RPP. Menurut Permendiknas No. 41 Tahun 2007 tentang Pembelajaran pada Pendidikan Dasar dan Pendidikan Menengah, RPP mencakup: “(1) identitas mata pelajaran, meliputi satuan pendidikan, kelas, semester, mata pelajaran/tema pelajaran, jumlah pertemuan, (2) standar kompetensi; (3) kompetensi dasar, (4) indikator pencapaian kompetensi, (5) tujuan pembelajaran, (6) materi ajar, (7) alokasi waktu, (8) metode pembelajaran, (9) kegiatan pembelajaran, (10) penilaian hasil belajar, (11) sumber belajar".

Perencanaan pembelajaran pada siklus II sudah disusun dengan baik dan sesuai dengan komponen RPP menurut Permendiknas No. 41 tahun 2007. Berdasarkan hasil pengamatan dan analisis data pada siklus II hasil yang diperoleh dalam perencanaan RPP sudah mencapai 92,86\% dengan kriteria sangat baik. Oleh karena itu dicukupkan sampai siklus II.

\section{Pelaksanaan}

Pelaksanaan pembelajaran haruslah mengikuti langkah-langkah bamboo dancing. Menurut Suprijono (2013:99) "langkahlangkah pelaksanaan pembelajaran haruslah sesuai dengan langkah-langkah bamboo dancing yaitu: (1) pengenalan topik, (2) pembentukan kelompok besar, membagikan tugas, (4) bergeser searah jarum jam untuk bertukar pasangan dalam berbagi informasi, (5) mempresentasikan hasil diskusi tiap-tiap kelompok besar".

Pelaksanaan pembelajaran pada siklus II baik itu pelaksanaan aspek guru maupun pelaksanaan aspek siswa sudah sesuai dengan langkah-langkah model bamboo dancing menurut Suprijono. Berdasarkan analisis data diperoleh hasil untuk pelaksanaan aspek guru 90\% dan pelaksanaan aspek siswa 95\% dengan kriteria sangat baik. Oleh karena itu tidak perlu dilanjutkan lagi ke siklus berikutnya.

\section{Hasil Belajar}

Rata-rata hasil belajar siklus II adalah 86,64 dengan persentase ketuntasan 100\%. Kunandar (2010:251) menyatakan bahwa "Kriteria ideal ketuntasan belajar masingmasing indikator adalah $75 \%$. Satuan pendidikan diharapkan meningkatkan ketuntasan belajar secara terus menerus untuk mencapai ketuntasan ideal. Ketuntasan ideal yaitu ketuntasan yang diharapkan yaitu 
$\geq 85 \%$ siswa mencapai batas KKM yang ditetapkan yaitu 75".

Jika dikaitkan dengan pendapat Kunandar tersebut maka hasil belajar yang diperoleh pada siklus II sudah mencapai hasil yang maksimal sehingga tidak perlu dilanjutkan ke siklus berikutnya.

\section{SIMPULAN}

Perencanaan pembelajaran PKn di kelas V SD dengan menggunakan model bamboo dancing dituangkan dalam bentuk RPP yang komponen penyusunnya terdiri dari standar kompetensi, kompetensi dasar, indikator, tujuan pembelajaran, materi pembelajaran, proses pembelajaran, metode pembelajaran, media dan sumber pembelajaran, serta penilaian pembelajaran. Penilaian RPP siklus I pertemuan 1 yaitu $78,57 \%$ (B). siklus I pertemuan 2 yaitu $85,7 \%$ (B) dengan perolehan rata-rata siklus I yaitu $82,14 \%$ (B) dan meningkat pada siklus II menjadi 92,86\% (SB). Pelaksanaan pembelajaran Pkn dengan menggunakan model bamboo dancing terdiri dari kegiatan awal, kegiatan inti, dan kegiatan akhir. Pelaksanaan pembelajaran dengan model bamboo dancing meliputi pelaksanaan dari aspek guru dan aspek siswa. Penilaian pelaksanaan pembelajaran pada aspek guru siklus I pertemuan 1 yaitu $75 \%$ (C), siklus 1 pertemuan 2 yaitu $80 \%$ (B) dengan perolehan rata-rata siklus $\mathrm{I} 77,5 \%$ (B) dan meningkat pada siklus II menjadi 90\% (SB). Penilaian pelaksanaan dari aspek siswa pada siklus I pertemuan 1 yaitu $77,5 \%$ (B), siklus I pertemuan 2 yaitu $85 \%$ (B) dengan perolehan rata-rata siklus $\mathrm{I} 81,25 \%$ (B) dan meningkat pada siklus II menjadi 95\% (SB). Hasil belajar siswa dengan menggunakan model kooperatif tipe bamboo dancing pada pembelajaran PKn di kelas V SD Negeri 16 Kampeh Kecanatan Baso mengalami peningkatan. Hal ini dapat dilihat dari nilai rata-rata hasil belajar siklus I pertemuan 1 yaitu 75,99, siklus I pertemuan 2 yaitu 80,96 dengan perolehan rata-rata siklus I yaitu 78,47 dan meningkat pada siklus II menjadi 86,64 .

\section{SARAN}

Sebelum pembelajaran, guru harus merancang Rencana Pelaksanaan Pembelajaran (RPP) sesuai dengan kurikulum dan model yang digunakan, khususnya model kooperatif tipe bamboo dancing. Langkahlangkah di dalam RPP haruslah sesuai dengan langkah-langkah model bamboo dancing itu sendiri. Pelaksanaan pembelajaran PKn dengan menggunakan model bamboo dancing hendaknya disesuaikan dengan rencana yang telah disusun dan disesuaikan dengan langkah-langkah model bamboo dancing yang digunakan. Agar hasil belajar siswa sesuai dengan yang diharapkan, guru hendaknya lebih memahami dan mampu menggunakan model bamboo dancing sebagai salah satu alalternatif model pembelajaran PKn.

\section{DAFTAR RUJUKAN}

Depdiknas. (2006). Kurikulum Tingkat Satuan Pendidikan Jenjang Pendidikan Dasar. Jakarta: Badan Standar Nasional Pendidikan.

Istarani. 2012. 58 Model Pembelajaran Inovatif. Medan: Media Persada. 
Kunandar. 2010. Langkah Mudah Penelitian

Tindakan Kelas Sebagai

Pengembangan Profesi Guru. Jakarta:

Rajawali Pers.

Permendiknas No. 41 Tahun 2007 tentang

Standar Proses Pendidikan Dasar dan Menengah.

Purwanto dan Ngalim. 2006. Prinsip-prinsip dan Teknik Evaluasi Pengajaran. Jakarta: PT. Remaja Rosda Karya.

Suprijono, Agus. 2013. Cooperative Learning Teori dan Aplikasi PAIKEM. Yogyakarta: Pustaka Pelajar.

Wardhani, dkk. 2007. Penelitian Tindakan Kelas. Jakarta: Universitas Terbuka. 